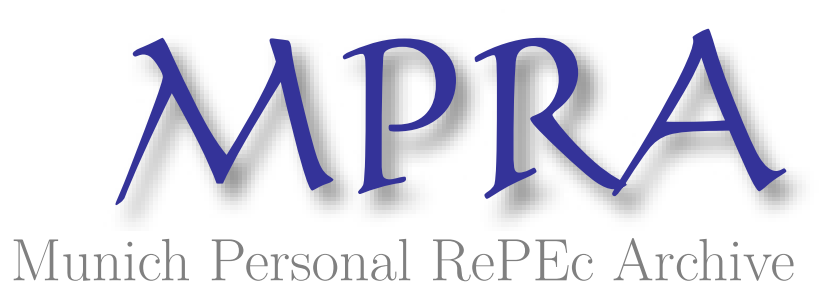

Credit risk measurement, leverage ratios and Basel III: proposed Basel III leverage and supplementary leverage ratios

Ojo, Marianne

North-West University

August 2014

Online at https://mpra.ub.uni-muenchen.de/59598/

MPRA Paper No. 59598, posted 01 Nov 2014 09:53 UTC 


\title{
Credit Risk Measurement, Leverage Ratios and Basel III: Proposed Basel III Leverage and Supplementary Leverage Ratios
}

\begin{abstract}
The Basel III Leverage Ratio, as originally agreed upon in December 2010, has recently undergone revisions and updates - both in relation to those proposed by the Basel Committee on Banking Supervision - as well as proposals introduced in the United States. Whilst recent proposals have been introduced by the Basel Committee to improve, particularly, the denominator component of the Leverage Ratio, new requirements have been introduced in the U.S to upgrade and increase these ratios, and it is those updates which relate to the Basel III Supplementary Leverage Ratio that have primarily generated a lot of interests. This is attributed not only to concerns that many subsidiaries of US Bank Holding Companies (BHCs) will find it cumbersome to meet such requirements, but also to potential or possible increases in regulatory capital arbitrage: a phenomenon which plagued the era of the original 1988 Basel Capital Accord and which also partially provided impetus for the introduction of Basel II.

This paper is aimed at providing an analysis of the recent updates which have taken place in respect of the Basel III Leverage Ratio and the Basel III Supplementary Leverage Ratio - both in respect of recent amendments introduced by the Basel Committee and proposals introduced in the United States.

As well as highlighting and addressing gaps which exist in the literature relating to liquidity risks, corporate governance and information asymmetries, by way of reference to pre-dominant based dispersed ownership systems and structures, as well as concentrated ownership systems and structures, this paper will also consider the consequences - as well as the impact - which the U.S Leverage ratios could have on Basel III. There are ongoing debates in relation to revision by the Basel Committee, as well as the most recent U.S proposals to update Basel III Leverage ratios and whilst these revisions have been welcomed to a large extent, in view of the need to address Tier One capital requirements and exposure criteria, there is every likelihood, indication, as well as tendency that many global systemically important banks (GSIBS), and particularly their subsidiaries, will resort to capital arbitrage. What is likely to be the impact of the recent proposals in the U.S.?

The recent U.S proposals are certainly very encouraging and should also serve as impetus for other jurisdictions to adopt a pro-active approach - particularly where existing ratios or standards appear to be inadequate. This paper also adopts the approach of evaluating the causes and consequences of the most recent updates by the Basel Committee, as well as those revisions which have taken place in the U.S, by attempting to balance the merits of the respective legislative updates and proposals. The value of adopting leverage ratios as a supplementary regulatory tool will also be illustrated by way of reference to the impact of the recent legislative changes on risk taking activities, as well as the need to also supplement capital adequacy requirements with the Basel Leverage ratios and the Basel liquidity standards.
\end{abstract}

Key Words: credit risk, liquidity risks, global systemically important banks (G-SIBs), leverage ratios, harmonization, accounting rules, capital arbitrage, disclosure, stress testing techniques, U.S Basel III Final Rule 


\title{
Credit Risk Measurement, Leverage Ratios and Basel III: Proposed Basel III Leverage and Supplementary Leverage Ratios
}

\author{
Marianne Ojo ${ }^{1}$
}

\section{A Introduction}

The first consultative paper on a new capital adequacy framework, which was issued by the Basel Committee on Banking Supervision, introduced the ,three pillar“ model which encompasses the minimum capital requirements, supervisory review and market discipline - ,as a lever to strengthen disclosure and encourage safe and sound bankingpractices.“2 As well as the criticism related to the fact that it rewarded risk lending, the fact that „,capital requirements were just reasonably related to banks' risk taking activities and that the credit exposure requirement was the same regardless of the credit rating of the borrower, ${ }^{63}$ a general criticism of Basel I relates to the fact that it promoted capital arbitrage. Such capital arbitrage being attributed to its wide risk categories which provided banks with the liberty to ,arbitrage between their economic assessment of risk and the regulatory capital requirements."

„Regulatory capital arbitrage“, a practice which involves banks ,using securitization to alter the profile of their book" usually produces the effect of making bank's capital ratios appear inflated. ${ }^{5}$ Four identified types of capital arbitrage are: ${ }^{6}$ cherry picking, securitization with partial recourse, remote origination and indirect credit.

The Second Consultative Paper, issued by the Basel Committee in January2001, introduced the two Internal Ratings Based (IRB) methodologies - the Foundational IRB and the Advanced IRB methodologies. The Internal Ratings Based approach to capital requirements for credit risk, not only relies significantly on the internal assessment carried out by a bank, in relation to counterparties and exposures, but is also geared towards the achievement of two primary goals, namely: ${ }^{7}$,additional risk sensitivity“ and ,incentive compatibility“.

Basel 2 is premised on a three level approach which permits banks to select from three models, namely: the basic standardized model, the IRB foundation approach and the advanced ratings approach. According to the

\footnotetext{
${ }^{1}$ Professor, Faculty of Commerce and Administration, North-West University Email: marianneojo@hotmail.com

2 Basel Committee on Banking Supervision, 'Consultative Paper on a New Capital Adequacy Framework' 3rd June $1999<\mathrm{http}: / /$ www.bis.org/press/p990603.htm>

${ }^{3}$ See M Saidenberg and T Schuermann, 'The New Basel Capital Accord and Questions for Research' (2003)

Wharton Financial Institutions Center Working Paper 2003 at page 4

${ }^{4}$ Basel Committee on Banking Supervision, 'Capital Requirements and Bank Behavior: The Impact of the Basel Accord' Basel Committee on Banking Supervision Working Papers April 1999 at page 21

5 See ibid; Bank's capital ratio may appear inflated „relative to the riskiness of the remaining exposure“

6 Ibid at pages $22-24$

7 In establishing an Internal Ratings Based approach, the Committee's intention was directed at „fine tuning capital requirements with a greater degree of accuracy to the level of a bank's exposure to credit risks." Basel Committee on Banking Supervision, 'The Internal Ratings Based Approach' Supporting Document to the New Basel Capital Accord 2001 at pages 1 and $3 \mathrm{http}: / /$ www.bis.org/publ/bcbsca05.pdf
} 
Consultative Document on Standard Approach to Credit Risk, ${ }^{8}$ capital requirements under the standardized approach are considered to be more synchronized and in harmony with the principal elements of banking risk - owing to the introduction of more differentiated risk weights and a broader recognition of techniques which are applied in mitigating risk whilst such techniques attempt to avoid undue complexity. As a result, capital ratios generated through the standardized approach, should adapt more to present and actual risks encountered by banks, than was the case previously.

Under Pillar One minimum capital requirements, operational risk is to be corroborated by capital. Measurement approaches for operational risk can be found in the Capital Requirements Directive (CRD) and there are three broad approaches to the capital assessment of operational risk which are as follows:

- Basic Indicator Approaches

- Standardized Approaches

- Internal Measurement Approach

The developments and evolution across the Basel Capital Accords have illustrated their focus to address prevailing financial risks at the time, their focus on the regulation of complex financial instruments such as hedge funds, the pro cyclical nature of risks and the need to mitigate occurrences related to regulatory capital arbitrage. The era of Basel III has also witnessed the introduction of liquidity standards - these being the first of their kind, However the need to address off balance sheet instruments, complex derivative products, exposures of various kinds - and particularly those exposures relating to derivatives, off balance sheet and leverage, as well as those risks attributed to non-bank institutions, continually constitute a vital focal point.

This paper is structured as follows: The next section introduces the literature review section whereby subsection BII highlights the gaps which exist in the current and previous literature on the topic - with particular reference to one fundamental risk and also complementary standards which are not discussed as extensively in this paper namely liquidity risks and the two liquidity ratios and standards (the Liquidity Coverage Ratio and the Net Stable Funding Ratio). Subsection BIII then considers the reasons attributable to the introduction of Basel III Leverage and Basel III Supplementary Leverage Ratios as well as its vital role as a supplementary measure to the risk based capital adequacy framework. Whilst highlighting the merits and advantages of the Basel Leverage Ratio, subsection BIII also illustrates why revisions and updates to the Basel Leverage Ratio were deemed necessary if the Basel Committee's broad goals and objectives of fostering financial stability are to be achieved. In this respect it also incorporates the background and factors which have provided the impetus for the recent proposals in the U.S - as well as those proposals and guidelines initiated by the Basel Committee on Banking Supervision in June 2013. From the perspective of the proposals undertaken in the U.S, factors such as the „Too Big To Fail Effect" are considered. Further, whilst the recent proposals in the U.S are to an extent, targeted at increasing the leverage ratios, those revisions currently being undertaken by the Basel Committee - as stated in the June 2013 guidelines, are, to an extent, targeted at revising the components of the Basel Leverage Ratios.

${ }^{8}$ Basel Committee on Banking Supervision, Consultative Document, Standard Approach to Credit Risk, Supporting Document to the New Basel Accord January 2001 at page $1 \mathrm{http} ; / /$ www.bis.org/publ/bcbsca04.pdf 
Section $C$ then considers the Basel Leverage Ratio's role as a supplementary measure to the risk-based capital adequacy framework, as well as the impact of the recent legislative proposals and changes on risk taking activities. Components of the Basel III Level Ratio and recent proposals aimed at updating such components are considered - with the aim of highlighting the importance of such updates in the minimization of regulatory capital arbitrage activities. Section D then considers not only the events leading up to (as well as culminating) in the 2013 Rule and the Final Rule, but also arguments put forward to bolster U.S proposals to update the Basel Leverage Ratio.

In concluding the paper, reference is made to the all-important need to achieve a balance between the need for consistency, comparability and improved harmonization whilst ensuring that simplicity and a „one size fits all“ approach does not promote a situation whereby credible and accurate results are neglected at the expense of achieving a standardized approach. This is partly illustrated by way of reference to bank stress testing techniques.

\section{B Basel III Liquidity Standards, Basel III Leverage and Basel III Supplementary Leverage Ratios: Complements to the Risk Based Capital Adequacy Framework}

Whilst the Liquidity Coverage Ratio (LCR)'s objective is aimed at ,promoting the short-term resilience of the liquidity risk profile of banks by ensuring that banks have an adequate stock of unencumbered high quality assets (HQLA) that can be converted easily and immediately into cash" to meet the liquidity needs of private markets for a 30 calendar day liquidity stress scenario, the Net Stable Funding Ratio (NSFR) is targeted at medium to longer term funding activities of banking institutions. By the very nature of the definition of these liquidity standards, the first to be introduced under Basel III, it is not difficult to comprehend why the Liquidity Coverage Ratio constitutes the more crucial standard.

The NSFR serves as a complementary standard to the LCR in serving to „limit over-reliance on short-term wholesale funding during times of buoyant market liquidity and encourage better assessment of liquidity risk across all on- and off-balance sheet items“ as well as a „minimum enforcement mechanism.“

As is the case with the two liquidity standards which are intended to serve as complementary measures to the risk- based capital adequacy framework, the Basel III Leverage Ratio was established by the Basel Committee as a non-risk based measure which is intended to serve as a supplement to the Basel risk based capital framework. The merits of the Leverage Ratio as a supplement to the risk based capital adequacy framework include: ${ }^{9}$ i) Its constrain of the build-up of leverage in the banking sector - which the risk based regime is not equipped to address; ii) Through a non-risk based „backstop“ which ultimately serves to protect against model risk, and the reduction of capital requirements, its reinforcement of risk based requirements; iii) Its role as a standardized measure that investors and counterparties can use in making comparisons between banks over a

\footnotetext{
${ }^{9}$ Basel Committee on Banking Supervision, Discussion Paper 'The Regulatory Framework: Balancing Risk Sensitivity, Simplicity and Comparability“ July 2013 Bank for International Settlements Publications at page 16
} 
period of time; iv) The establishment by certain academics that the leverage ratio is a "statistically significant“ predictor of potential bank failures.

Hence it can be illustrated that the Basel III Leverage ratio not only serves as a supplementary measure to the risk based capital adequacy framework, but also a means whereby the facilitation of greater comparability between banks can be achieved (since standardization promotes consistency, enhanced transparency and disclosure). It vital role as a supplementary tool to the risk based capital adequacy framework in countering risk taking incentives will later be highlighted under section B II - which immediately follows this section.

- An underlying feature of the financial crisis was the build-up of excessive on- and off-balance sheet leverage in the banking system. In many cases, banks built up excessive leverage while maintaining strong risk-based capital ratios. At the height of the crisis, the market forced the banking sector to reduce its leverage in a manner that amplified downward pressure on asset prices. This deleveraging process exacerbated the feedback loop between losses, falling bank capital, and shrinking credit availability. ${ }^{10}$

The Basel III reforms introduced a ,simple, transparent, non-risk based leverage ratio which is intended to serve - not only as a „,credible supplementary measure to the risk-based capital requirements“ but also: ${ }^{11}$

- restrict the build-up of leverage in the banking sector to avoid destabilizing deleveraging processes that can damage the broader financial system and the economy; and

- re-inforce the risk-based requirements with a simple, non-risk-based "backstop" measure.

Furthermore, the Basel Committee is of the view that: ${ }^{12}$

- a simple leverage ratio framework is critical and complementary to the risk-based capital framework; and

- a credible leverage ratio is one that ensures broad and adequate capture of both the on- and off-balance sheet leverage of banks.

The ensuing sub section is not only aimed at addressing gaps in the literature on liquidity risk, but also to highlight why pre dominantly based dispersed ownership structures - such as those which prevail in the United Kingdom and the United States, need to focus more on the issues related to liquidity risk, whilst concentrated ownership based structures and systems (inclusive of family firms) need to focus on their accounting frameworks, the vital role played by audit committees and audits, in order to ensure that objectives of the Basel risk based capital framework, as well as certain corporate governance objectives are fulfilled.

\footnotetext{
${ }^{10}$ Basel Committee on Banking Supervision, Consultative Document Revised Basel III Leverage Ratio Framework and Disclosure Requirements June 2013 at page 4 of $22 \mathrm{http}: / / w w w . b i s . o r g / p u b l / b c b s 251 . p d f$

${ }^{11}$ ibid

${ }^{12} \mathrm{ibid}$
} 


\section{B II Accounting For the Gaps in the Literature on Corporate Governance and Information Asymmetries: Liquidity Risk}

It has been argued in many studies, that bank capital ratios and several other financial indicators do not serve as effectively in emerging market economies ( as is the case with industrial nations). According to Rojas-Suarez (2002), the capital-to-asset ratio, has under-performed as an indicator of banking crisis related problems in Latin America and Asia. ${ }^{13}$

Two reasons which have been put forward as explanations for this are: ${ }^{14}$

- Severe deficiencies in the accounting and regulatory framework in these jurisdictions;

- Lack of liquid markets for bank shares, subordinated debt and other bank liabilities and assets which are required to confirm and justify the actual worth of a bank - rather than merely its accounting value.

To which it will also be added that audits, which serve as vital signaling mechanisms in capital markets, have limited roles in many emerging economies than is the case with more industrialized nations.

Even though it is widely acknowledged that systems founded on concentrated ownership systems (that is, where a dominant shareholder prevails) are less susceptible to information asymmetries, it cannot be conclusively argued that such systems are immune from or less culpable of those issues associated with lack of transparency and inadequate disclosure requirements.

Regardless of the distinctive features which may exist between family firms and those other firms which are not family-run, but which are predominantly based on concentrated ownership systems and structures, one common feature between these concentrated ownership based structured firms and enterprises is, namely, their reduced dependence on audits and audit committees - as well as the existence of relatively thin audit markets, when compared to their pre- dominantly based dispersed ownership counterparts (and mainly industrial nations where the demand for audits, and audit markets are much greater).

Audits are regarded as vital signaling mechanisms which are supposed to reduce information asymmetries - if such audits provide credibility to the financial statements (on which opinions are provided and relied upon by shareholders and investors) as they should. Furthermore, disclosure stringent accounting, audit requirements which operate in many capital market economies and predominantly based dispersed ownership systems and structures, should serve as means of fostering greater transparency, disclosure and accountability.

Hence should it still be concluded that structures based on concentrated ownership models are less susceptible to information asymmetries and "free-rider" problems?

The definition of liquidity, as provided by the Bank of International Settlements (BIS), is "the ability of a bank to fund increases in assets and meet obligations as they come due, without incurring unacceptable losses. The

${ }^{13}$ L Rojas-Suarez, ,Rating Banks in Emerging Markets: What Credit Agencies Should Learn From Financial Indicators (2002) http://papers.ssrn.com/sol3/papers.cfm?abstract_id=300891

${ }^{14}$ ibid 
fundamental role of banks in the maturity transformation of short-term deposits into long-term loans makes banks inherently vulnerable to liquidity risk, both of an institution-specific nature and that which affects markets as a whole." 15

A liquidity crisis is considered to be ,the classic type of banking crisis whereby a bank for some reason, cannot meet all its payment obligations. "16 The role played by imperfect knowledge in triggering such a crisis is further elaborated. In this sense, bank runs are triggered as a result of such, ,imperfect knowledge which customers have of their banks, and the links through the interbank market and payment system. ${ }^{\text {“17 }}$ Such role played by imperfect knowledge or information asymmetries in triggering such crises could also be extended to enterprises, firms and organizations - and not just banking organizations.

Results obtained by Fu, Lu-Andrews and Yu-Thompson ${ }^{18}$ reveal that family firms incorporated in their study, with better quality of corporate governance mechanisms, are associated with higher levels of corporate liquidity and stock liquidity, as well as lower level of liquidity risk. Whilst the issue relating to reduced information asymmetries with concentrated ownership structures (in comparison with predominantly based dispersed ownership systems and structures) appears less contentious, a more contentious issue is that relating to whether better corporate governance mechanisms operate in concentrated ownership structures than is the case with predominantly based dispersed ownership structures and systems. Audit committees, whose operation are more common and widespread in predominantly based dispersed ownership structures, are by definition, considered to be "internal monitoring devices which are supportive of good corporate governance practices."

The Cadbury definition of corporate governance, that is, "the system whereby companies and directors are directed and controlled" or a structure whereby those enterprises are governed and directed, as well as certain vital elements of corporate governance, namely: supervision, monitoring, accountability, transparency and disclosure, have profound repercussions in the evaluation of how well corporate governance mechanisms operate in dispersed ownership systems - as well as in relation to concentrated ownership structures or systems.

According to Bennedsen, Perez- Gonzalez and Wolfenzon, ${ }^{19}$ "the main governance issue facing family firms is balancing the benefits associated with having a controlling family with the challenges the structure imposes on minority shareholders. Common governance mechanisms are less likely to be effective whenever control and decision rights are concentrated around a family."

Further, is it widely acknowledged in the literature that even though dispersed ownership firms usually encounter the traditional principal agent problem, conflicts of interests between controlling shareholders and

\footnotetext{
15 Principles for Sound Liquidity Risk Management and Supervision Sept 2008 at p 1 $<$ http://www.bis.org/publ/bcbs144.htm>

${ }^{16}$ See RM Lastra and G Wood, „The Crisis of 2007 - 09: Nature, Causes and Reactions“ Journal of International Economic Law 13(3) at pages 531 and 532

17 ibid

${ }^{18} \mathrm{~L} \mathrm{Fu}, \mathrm{R}$ Lu-Andrews and Y Y-Thompson "Liquidity and Corporate Governance: Evidence From Family Firms" http://papers.ssrn.com/sol3/papers.cfm?abstract_id=2433764

${ }^{19}$ M Bennedsen, F Perez-Gonzalez and D Wolfenzon" " The Governance of Family

Firms" http://web.stanford.edu/ fperezg/familyfirmresearch.pdf
} 
non-controlling shareholders (minority shareholders) are more prevalent with concentrated ownership structures. $^{20}$

With respect to corporate governance, effects of family owned firms on performance could be considered to be another distinctive feature - in addition to blood relations involved in the control of family-run firms - when comparing and contrasting with other firms which are based on concentrated ownership structures but not run by family or blood relations. Resources available to family-run firms to conduct full scale audits, the structure of the firm, whether CEO and other duties are adequately segregated or all performed by the same individual, as well as the competence or qualifications required to effectively supervise or engage auditors, are all decisive and contributory in the determination of whether adequate accountability, supervision, monitoring, transparency and disclosure requirements are met in fulfilling corporate governance criteria.

Even though the ensuing subsection is exclusively dedicated to highlighting the benefits of the Basel Leverage Ratio, reasons for recent proposals aimed at updating the originally introduced Basel Leverage Ratio will be considered in the ensuing section. From the discussions related to predominantly-based dispersed ownership systems and concentrated ownership structures, it can easily be seen why the risk based capital adequacy framework is of such vital importance to capital market based economies such as the United Kingdom and the United States. However greater focus will be required in relation to liquidity risks in these systems - just as more efforts are required to upgrade the status of audits and audit committees in many concentrated ownership based systems and structures.

\section{B.III Basel Committee's Efforts to Update Original 2010 Basel III Leverage Ratios and U.S Proposals to Increase Basel Leverage Ratios}

In November 2011, the Basel Committee on Banking Supervision (BCBS) issued a document, ${ }^{21}$ „Global Systemically Important Banks: Assessment Methodology and the Additional Loss Absorbency Requirement, which ,sets out a framework for a new capital surcharge for global systemically important banks (the BCBS framework)."

The BCBS framework:

- Is intended to strengthen the capital position of the global systemically important banking organizations (GSIBs) beyond the requirements of other banking organizations by expanding the capital conservation buffer for these organizations.

- Incorporates five broad characteristics of a banking organization that the agencies consider to be good proxies for, and correlated with, systemic importance - size, complexity, interconnectedness, lack of substitutes, and cross-border activity.

\footnotetext{
${ }^{20}$ See M Ojo, "Why the Traditional Principal Agent Theory May No Longer Apply to Concentrated Ownership Systems and Structures" http://mpra.ub.uni-muenchen.de/50832/1/MPRA_paper_50832.pdf

${ }^{21}$ Basel Committee for Banking Supervision, 'Global Systemically Important Banks: Assessment Methodology and the Additional Loss Absorbency Requirement' July 2013 http://www.bis.org/publ/bcbs207.pdf
} 
The document „Global Systemically Important Banks: Updated Assessment Methodology and the Higher Loss Absorbency Requirement" updates and replaces the November 2011 publication Global Systemically Important Banks: Assessment Methodology and the Additional Loss Absorbency Requirement. According to the Committee, changes in relation to the updated publication reflect the lessons learnt from applying the assessment methodology using data submitted by banks in respect of their positions as at the financial year-ends 2009 to 2011. Further, it is highlighted that the changes also include the addition of the disclosures that banks are required to make to ensure that the assessment methodology operates on the basis of publicly available information. Further changes related to the publication are as follows:

- Methodology for determining the sample of banks.

- Indicator definitions.

- The Wholesale Funding Ratio, which was one of the three indicators in the interconnectedness category in the November 2011 publication and which has been replaced with a Securities Outstanding indicator.

Several revisions, particularly relating to the denominator component of the Basel III Leverage Ratio, have recently been undertaken by the Basel Committee, as illustrated in its June 2013 Guidelines, and more recently, its January 2014 Standard. From this viewpoint, measures aimed at minimizing regulatory capital arbitrage become all the more evident since banks are able to manipulate their way into increasing the leverage ratio by getting many assets allowed in the numerator and as little in the denominator:,,cherry picking“ arbitrage having constituted a problem since the original Basel Capital Accord. Hence it could be argued that it is not the mere increase of leverage ratios that truly matters (even though this is also important), but measures aimed at ensuring that permissible contents/instruments are incorporated into the numerators and denominators of such leverage ratios.

Certain factors influential in the recent proposals and efforts aimed at achieving higher leverage capital requirements, according to U.S federal agencies, ${ }^{22}$ include the belief that higher standards for the supplementary leverage ratio would reduce the likelihood of resolutions, and would allow regulators more time to tailor resolution efforts in the event those are needed. In their opinion, by further constraining their use of leverage, higher leverage standards could offset possible funding cost advantages that these institutions may enjoy as a result of the "too-big-to-fail" problem, which will be considered in the following section.

${ }^{22}$ See Federal Reserve, 'Regulatory Capital Rules: Regulatory Capital, Enhanced Supplementary Leverage Ratio Standards for Certain Bank Holding Companies and their Subsidiary Insured Depository Institutions' at page 11 http://www.federalreserve.gov/newsevents/press/bcreg/bcreg20130709a1.pdf. 
The Too Big to Fail Problem and Its Impact on Recent Legislative Proposals

According to a notice jointly issued by the Office of the Comptroller of the Currency, Treasury; the Board of Governors of the Federal Reserve System, and the Federal Deposit Insurance, ,the perception continues to persist in the markets that some companies remain "too big to fail," - posing, in their view, an ongoing threat to the financial system. ${ }^{23}$ It is also added that: ${ }^{24}$

- First, the existence of the "too-big-to-fail" problem reduces the incentives of shareholders, creditors and counterparties of these companies to discipline excessive risk-taking by the companies.

- Second, it produces competitive distortions because companies perceived as "too big to fail" can often fund themselves at a lower cost than other companies. This distortion being regarded as unfair to smaller companies, damaging to fair competition, and such distortion tends to artificially encourage further consolidation and concentration in the financial system.

As well as the important objective of the Dodd-Frank Wall Street Reform and Consumer Protection Act of 2010 (Dodd-Frank Act) aimed at ,mitigating the threat to financial stability posed by systemically-important financial companies ${ }^{625}$ another vital and important means of fostering financial stability in averting another Financial Crisis, safeguarding and assisting financial institutions to navigate periods of financial or economic stress, in the agencies' experience, is strong capital. In their opinion, the „maintenance of a strong base of capital at the largest, systemically important institutions is particularly important because capital shortfalls at these institutions can contribute to systemic distress and can have material adverse economic effects. Further, they contend that higher capital standards for such institutions would place additional private capital at risk before the Federal deposit insurance fund and the Federal government's resolution mechanisms would be called upon, and reduce the likelihood of economic disruptions caused by problems at these institutions. ${ }^{26}$

\section{The Basel Leverage Ratio's Role as a Supplementary Measure to The Risk Based Capital Adequacy Framework}

According to Valladares, the June 2013 proposed leverage ratios by the Basel Committee, is a necessary supplement to the current risk-weighted asset credit risk measurement and is crucial to making banks better capitalized to sustain unexpected losses. ${ }^{27}$ Even though many criticisms have arisen in relation to the risk taking

${ }^{23}$ See Federal Reserve, 'Regulatory Capital Rules: Regulatory Capital, Enhanced Supplementary Leverage Ratio Standards for Certain Bank Holding Companies and their Subsidiary Insured Depository Institutions' at page 7 http://www.federalreserve.gov/newsevents/press/bcreg/bcreg20130709a1.pdf.

${ }^{24}$ ibid

${ }^{25}$ Federal Reserve, 'Regulatory Capital Rules: Regulatory Capital, Enhanced Supplementary Leverage Ratio Standards for Certain Bank Holding Companies and their Subsidiary Insured Depository Institutions' page 8

${ }^{26}$ Ibid at page 11

${ }^{27}$ M Rodriguez Valladares, 'Why Basel' Latest Leverage Ratio is Better' http://www.americanbanker.com/bankthink/why-basels-latest-leverage-ratio-is-better-1060635

1.html 
incentives that could be induced by such recent Basel leverage proposals, the following observations highlight the importance of incorporating and supplementing risk based capital ratios, leverage ratios and the liquidity requirements with themselves since the implementation of one ratio in isolation, as will be highlighted, is likely to facilitate the tendencies for riskier ventures:

Valladares raises the point that even though critics of the proposed Basel guidelines argue that the leverage ratio would encourage banks to transact riskier on- or off-balance sheet instruments, that:

- if banks were to do so, such added riskiness would, however, raise banks' RWAs and force them to increase their capital. This action would also impact their liquidity coverage ratio by making the banks less liquid since most risky assets do not count for the LCR - which is another reason why the leverage ratio is an important complement to the RWA and liquidity buffers. ${ }^{28}$

In bolstering this viewpoint, Bundesbank Vice President Sabine Lautenschlaeger has reiterated that ,the leverage ratio shouldn't be the main gauge because it doesn't demand more capital to back the more loss-prone investments, and thus can give bankers "unhealthy incentives" to take on more risk."

In accentuating the need for its complementary function and role to the risk-based capital framework, the Basel leverage ratios must be linked to the risk based capital adequacy framework - both in respect of their calculations, metrics and measures, as well as primary objectives and goals in introducing such leverage ratios. Some of the objectives for originally introducing leverage ratios in 2010 being the creation of a "secondary metric which was simple and transparent - whereby regulators could assess balance sheet sizes appropriately" as well as the need to facilitate more consistent modes of measurements of risk weighted assets.

In its aims to address concerns raised by the Basel Committee's June 2013 consultative paper, namely concerns that the Consultative Paper's definition of exposure was "too expansive", that is, "the leverage ratio's denominator was too large" 29 changes have been made to the June 2013 paper, as evidenced by the more recent January 2014 update and the April 2014 Final Standard for measuring and controlling large exposures. These changes introduce a more simplistic, consistent approach to the measurement of exposures through incorporating the use of credit conversion factors (CCFs).

\footnotetext{
${ }^{28}$ ibid

${ }^{29}$ See PricewaterhouseCoopers, "Regulatory Brief: Basel Leverage Ratios: No Cover For US Banks" January 2014 http://www.pwc.com/en_US/us/financial-services/regulatory-services/publications/assets/fs-reg-brief-dodd-frank-basel-leve rage-ratio.pdf Also see Basel Committee on Banking Supervision, "Supervisory Framework for Measuring and Controlling Large Exposures - Final Standard"

See particularly paragraph 35 "For the purpose of the large exposures framework, off-balance sheet items will be converted into credit exposure equivalents through the use of credit conversion factors (CCFs) by applying the CCFs set out for the standardized approach for credit risk for risk -based capital requirements, with a floor of $10 \%$. " http://www.bis.org/publ/bcbs283.htm and

Basel Committee on Banking Supervision, Consultative Document: The Non Internal Model Method for Capitalizing Counterparty Credit Risk Exposures (June 2013) http://www.bis.org/publ/bcbs254.htm and:

Basel Committee on Banking Supervision, "The Standardized Approach for Measuring Counterparty Credit Risk Exposures (March 2014) Available at http://www.bis.org/publ/bcbs279.htm
} 
According to the January 2014 revised leverage ratio standard, ${ }^{30}$ in the risk based capital framework, off balance sheet items are converted under the standardized approach into credit exposure equivalents through the use of credit conversion factors. It is also stipulated that the CCFs set out in paragraphs 14-22 of its Annex must be applied to notional amounts - for purposes of determining the exposure amount of Off Balance Sheet (OBS) items for leverage ratio.

\section{C.II Components of the Basel III Leverage Ratio and Recent Updates to the Components}

The Basel III Leverage Ratio is defined as the Capital Measure (the numerator) divided by the Exposure Measure (the denominator), with this ratio expressed as a percentage and with the basis of calculation being the average of the three month-end leverage ratios over a quarter. ${ }^{31}$ As reported by DB Research, the Basel Committee's issuance of its consultation paper on common definitions for the non-binding leverage ratio enshrined in Basel III, is not only considered to be an indication of a clear preference to move to a binding leverage ratio, the new Basel definition, it is further contended, would ,disallow much of the derivatives netting which had seen US banks post substantially stronger leverage ratios than most European institutions." 32

As highlighted under section $\mathrm{B}$, one of the goals of leverage ratios, as intended by the Basel Committee on Banking Supervision, is to ensure that both on and off balance sheet leverage of banks are adequately captured and accounted for. Given the revisions which have occurred, following the introduction of the original 2010 Basel Leverage Ratios, it would be expected that subsequent revisions would have the effect of expanding the denominator component, namely the exposure component - as a means of highlighting the commitment to expand the horizons being accounted for, as regards exposures - particularly credit exposures. Even though the numerator component, comprising Tier One capital of the risk-based capital framework, is also important, in line with the goals of adequately capturing on and off balance sheet exposures, the importance of focusing on the denominator component (which comprises of the exposure measure) of the Basel III Leverage Ratio is also illustrated thus:

\footnotetext{
${ }^{30}$ see paragraph 39 Basel Committee on Banking Supervision, "Basel III Leverage Ratio Framework and Disclosure Requirements" January 2014

${ }^{31}$ Basel Committee on Banking Supervision, Consultative Document Revised Basel III Leverage Ratio Framework and Disclosure Requirements at page 5 of $22 \mathrm{http}: / / w w w . b i s . o r g / p u b l / b c b s 251 . p d f$

${ }^{32}$ DB Research, "Leverage Ratio: Pressure on Europe is Rising" http://www.dbresearch.de/servlet/reweb2.ReWEB? addmenu $=$ false $\&$ document $=$ PROD0000000000317297\&rdShowArchivedDocus $=$ true\&rwnode $=$ DBR_INTERNET _DE-PROD\$NAVIGATION\&rwobj=ReDisplay.Start.class\&rwsite=DBR_INTERNET_DE-PROD
} 
Components of the Exposure Measure

A bank's exposure measure is considered to be the sum of the following:

- On balance sheet exposures

- Derivative exposures

- Securities Financing Transaction Exposures

- $\quad$ Off balance sheet (OBS) items

According to the most recent, updated Standard on leverage ratios (hereinafter referred to as "the Final Standard"), issued by the Basel Committee on Banking Supervision in January2014, ${ }^{33}$ the exposure measure for the leverage ratio, should generally, follow the accounting value, subject to the following:

- On-balance sheet, non derivative exposures are included in the exposure measure net of specific provisions or accounting valuation adjustments;

- $\quad$ Netting of loans and deposits is NOT allowed.

As well as disallowing the "netting" of loans and deposits, the January2014 finalstandard ${ }^{34}$ on leverage ratios, as issued by the Basel Committee on Banking Supervision, incompliance with the June revision, also provides under paragraph 30 that, in order to capture the credit exposure to the underlying reference entity, in addition to the prescribed CCR treatment for derivatives and related collateral, the effective notional amount referenced by a written credit derivative is to be included in the exposure measure.

However, in contrast to its predecessor, which highlighted under paragraph 27 that:

- collateral received in connection with derivative contracts does not reduce the economic leverage inherent in a bank's derivatives position. In particular, the exposure arising from the contract underlying is not reduced. As such, collateral received (cash or non-cash) may not be netted against derivatives exposures whether or not netting is permitted under the bank's operative accounting or risk-based framework

the Final Standard, paragraph 23 projects a more lenient and cautious tone in its approach to netting:

- collateral received in connection with derivative contracts does not necessarily reduce the leverage inherent in a bank's derivatives position, which is generally the case if the settlement exposure arising from the underlying derivative contract is not reduced. As a general rule, collateral received may not be netted against derivative exposures whether or not netting is permitted under the bank's operative accounting or risk-based framework. Hence, when calculating the exposure amount by applying paragraphs 19 to 21 above, a bank must not reduce the exposure amount by any collateral received from the counterparty.

Furthermore, extended provisions have been included to permit certain netting transactions between counterparties - to the extent that certain provisions and conditions stipulated in the Final Standard are met.

\footnotetext{
${ }^{33}$ Basel Committee on Banking Supervision, "Basel III Leverage Ratio Framework and Disclosure Requirements" January 2014 Bank for International Settlements Publications, see paragraph 12. It is however contended that this version is a "near final version".

34 Basel Committee on Banking Supervision, "Basel III Leverage Ratio Framework and Disclosure Requirements" January 2014 Bank for International Settlements Publications
} 
As a means of ensuring consistency, comparability and accuracy in its calculations and measurements, the same coverage as that adopted for regulatory consolidation - as used within the risk-based capital framework, is applied by the Basel III leverage ratio framework.

In contrast to many other jurisdictions, the U.S has introduced proposals aimed at enhancing the Basel III leverage ratios, (the recently revised Supplementary Leverage ratios), as well as the Dodd Frank Leverage Ratio. $^{35}$

Recent proposals aimed at enhancing the Basel III leverage ratios in the U.S would result in an increase to 5 percent of assets for parent companies and 6 percent for their banking subsidiaries under a proposal which will affect the eight globally systemically important banks in the U.S. In November 2012, the FSB and BCBS published a list of banks that meet the Basel Committee for Banking Supervision definition of a G-SIB based on year-end 2011 data. The eight globally systemically important banks in the U.S, identified as G-SIBs by the Financial Stability Board, are: Bank of America Corporation, The Bank of New York Mellon Corporation, Citigroup Inc., Goldman Sachs Group, Inc., JP Morgan Chase \& Co., Morgan Stanley, State Street Corporation and Wells Fargo \& Company. ${ }^{36}$

\section{The 2013 Rule and the Final Rule}

The 2013 Rule „revised and replaced the agencies’ risk-based and leverage capital standards and established a 3 percent minimum supplementary leverage ratio for banking organizations subject to the agencies' advanced approaches risk-based capital rules. ${ }^{\text {“37 }}$ The 2013 rule was adopted as a final rule on July 2, 2013.

Moreover, this final rule:

- Implements a revised definition of regulatory capital;

- A new common equity tier 1 minimum capital requirement;

- A higher minimum tier 1 capital requirement; and

35 "Dodd Frank section 165 compels foreign banks to comply with banking rules. Whereas eight of the largest U.S banks meet the 3\% ratio, many foreign banks are permitted to meet the $4 \%$ ratio". See S Skyrm, "New Regulation and the Repo Market: Leverage Ratios" http://scottskyrm.com/2014/03/new-regulation-and-the-repo-market-leverageratios/

${ }^{36}$ See Financial Stability Board, Update of Group of Global Systemically Important Banks (G-SIBs) (Nov. 1, 2012) http://www.financialstabilityboard.org/publications/r_121031ac.pdf

${ }^{37}$ See Federal Reserve, 'Regulatory Capital Rules: Regulatory Capital, Enhanced Supplementary Leverage Ratio Standards for Certain Bank Holding Companies and their Subsidiary Insured Depository Institutions' at page 12 http://www.federalreserve.gov/newsevents/press/bcreg/bcreg20130709a1.pdf. and also Federal Reserve, 'Federal Reserve Approves Final Rule...' ," The final rule minimizes burden on smaller, less complex financial institutions. It establishes an integrated regulatory capital framework that addresses shortcomings in capital requirements, particularly for larger, internationally active banking organizations, that became apparent during the recent financial crisis. The rule will implement in the United States the Basel III regulatory capital reforms from the Basel Committee on Banking Supervision and certain changes required by the Dodd-Frank Wall Street Reform and Consumer Protection Act." See $<\mathrm{http}: / /$ www.federalreserve.gov/newsevents/press/bcreg/20130702a.htm> 
For banking organizations subject to the advanced approaches risk-based capital rules, a supplementary leverage ratio that incorporates a broader set of exposures in the denominator. ${ }^{38}$

Following the publication of the U.S Basel III Final Rule, many U.S banking agencies proposed higher leverage capital requirements for the eight U.S bank holding companies (BHCs) which have been identified by the Financial Stability Board, as global systemically important banks (,referred to as „covered BHCs“) and their insured depository institution(IDI) subsidiaries :namely, Bank of America Corporation, The Bank of New York Mellon Corporation, Citigroup Inc., Goldman Sachs Group, Inc., JP Morgan Chase \& Co., Morgan Stanley, State Street Corporation and Wells Fargo \& Company.

An overview of some of the differences between the revised Basel III Leverage Ratios (as reflected by the January 2014 update) and the US Supplementary Leverage Ratios is illustrated in the following table: ${ }^{39}$

Source: http://blog.usbasel3.com/category/leverage-ratios/

\begin{tabular}{|c|c|c|}
\hline Topic & $\begin{array}{l}\text { Revised Basel III Leverage Ratio } \\
\text { (Jan. 2014) }\end{array}$ & $\begin{array}{l}\text { Supplementary Leverage Ratio (SLR) } \\
\text { (including Apr. } 2014 \text { proposed denominator revisions) }\end{array}$ \\
\hline Level of the ratio & $\begin{array}{l}\text { - } 3 \% \text { minimum } \\
\text { - Basplies to "internationally active banks" } \\
2014 \text { : "Only now that we have an agreed [measure } \\
\text { of leverage exposure] can the Committee begin to } \\
\text { turn to the issue of calibration, and the relationship } \\
\text { of the leverage ratio to the risk-based framework. } \\
\text { We have quite a bit of work to do to get this } \\
\text { balance right." }\end{array}$ & $\begin{array}{l}\text { - } 3 \% \text { minimum for advanced approaches banking } \\
\text { organizations and advanced approaches U.S. } \\
\text { intermediate holding companies ("IHCS") of foreign } \\
\text { banks } \\
\text { - Surcharge for } 8 \text { U.S. global systemically important } \\
\text { banks ("G-SIBs") and their U.S. insured depository } \\
\text { institutions ("IDI") subsidiaries (>5\% for consolidated } \\
\text { group and } 6 \% \text { for IDI subsidiaries) }\end{array}$ \\
\hline
\end{tabular}

\footnotetext{
${ }^{38}$ See Federal Reserve, Regulatory Capital Rules: Regulatory Capital, Implementation of Basel III, Capital Adequacy, Transition Provisions, Prompt Corrective Action, Standardized Approach for Risk-weighted Assets, Market Discipline and Disclosure Requirements, Advanced Approaches Risk-Based Capital Rule, and Market Risk Capital Rule http://www.federalreserve.gov/bcreg20130702a.pdf
}

${ }^{39}$ See D Polk, Visual Comparison Chart : US Supplementary Leverage Ratio (SLR) vs Basel III Leverage Ratio 


\begin{tabular}{|c|c|c|}
\hline Topic & $\begin{array}{l}\text { Revised Basel III Leverage Ratio } \\
\text { (Jan. 2014) }\end{array}$ & $\begin{array}{l}\text { Supplementary Leverage Ratio (SLR) } \\
\text { (including Apr. } 2014 \text { proposed denominator revisions) }\end{array}$ \\
\hline & $\underset{\substack{\text { Lasel III } \\
\text { Ratio }}}{\text { Revage }}=\frac{\text { Tier } 1 \text { Capital }}{\text { Exposure Measure }}$ & SLR $=\frac{\text { Tier } 1 \text { Capital }}{\text { Total Leverage Exposure }}$ \\
\hline Numerator & $\begin{array}{l}\text { - Tier } 1 \text { capital as defined in Basel III, taking into } \\
\text { account transitional arrangements } \\
\text { - Basel Committee will "track the impact" of using } \\
\text { either Common Equity Tier } 1 \text { capital or total capital } \\
\text { as the numerator }\end{array}$ & $\begin{array}{l}\text { - Tier } 1 \text { capital as defined in the U.S. Basel III final rule, } \\
\text { taking into account transitional arrangements }\end{array}$ \\
\hline DenomInator & $\begin{array}{l}\text { - Exposure Measure (components discussed } \\
\text { below) }\end{array}$ & $\begin{array}{l}\text { - Total Leverage Exposure (components discussed } \\
\text { below) }\end{array}$ \\
\hline $\begin{array}{l}\text { Frequency of } \\
\text { calculation }\end{array}$ & $\begin{array}{l}\text { - Not specifically addressed in January } 2014 \\
\text { revisions } \\
\text { - July } 2013 \text { consultative document: "The basis of } \\
\text { calculation is the average of the three month-end } \\
\text { leverage ratios over a quarter." }\end{array}$ & $\begin{array}{l}\text { - Tier } 1 \text { capital (numerator) is calculated as of the last day } \\
\text { of each reporting quarter } \\
\text { - Total Leverage Exposure (denominator) is calculated as } \\
\text { the arithmetic mean of the Total Leverage Exposure } \\
\text { calculated each day of the reporting quarter }\end{array}$ \\
\hline $\begin{array}{l}\text { Compllance } \\
\text { timing }\end{array}$ & $\begin{array}{l}\text { - January 1, 2018: Becomes a minimum } \\
\text { requirement after any final calibration and } \\
\text { adjustments } \\
\text { - January 1, 2015: Public disclosure begins }\end{array}$ & $\begin{array}{l}\text { - January 1, 2018: SLR becomes a minimum } \\
\text { requirement and SLR surcharge for U.S. G-SIBs } \\
\text { becomes effective } \\
\text { - January 1, 2015: Public disclosure begins }\end{array}$ \\
\hline
\end{tabular}

\section{Arguments put forward by US Federal Agencies in Support of Recent Proposals}

According to a report by the Federal Reserve, the following arguments were provided in support of the need for revisions to the Basel Leverage Ratios: ${ }^{40}$

- BCBS's approach for determining the minimum level of the Basel III leverage ratio was different than the calibration approach described above for the risk-based capital ratios.

- The BCBS used the most loss-absorbing measure of capital, common equity tier 1 capital, as the basis for calibration for the risk-based capital ratios, but not for the Basel III leverage ratio. In addition, the BCBS did not the minimum Basel III leverage ratio to meet explicit loss absorption and market confidence objectives

${ }^{40}$ Federal Reserve, 'Regulatory Capital Rules: Regulatory Capital, Enhanced Supplementary Leverage Ratio Standards for Certain Bank Holding Companies and their Subsidiary Insured Depository Institutions' pp 16 and 17 
- $\quad$ as it did in calibrating the minimum risk-based capital requirements and did not implement a capital conservation buffer level above the minimum leverage ratio. Rather, the BCBS focused on calibrating the Basel III leverage ratio to be a backstop to the risk-based capital ratios and an overall constraint on leverage.

- The agencies believe that while the establishment of the Basel III leverage ratio internationally is an important achievement, further steps could be taken to ensure that the risk- based and leverage capital requirements effectively work together to enhance the safety and soundness of the largest, most systemically important banking organizations.

Furthermore, the agencies are of the opinion that the proposed rule would permit covered BHCs and their IDI subsidiaries to fund themselves more than 90 percent with debt while still satisfying the proposed leverage thresholds. $^{41}$

Having highlighted the above, general consensus appears to favor proposals relating to the increase of Basel Leverage ratios in the U.S - with many commentators having considered the previous ratios to be inadequate.

\section{Arguments Favoring 2013 Basel Committee Revisions over those Updates Made to Basel Leverage Ratios in the U.S}

In commencing this section, it needs to be highlighted that the recent moves and proposals in the U.S, in relation to the Basel Leverage Ratio, are very much welcomed and quite encouraging given the prior concerns that the implementation of Basel rules, regulations and initiatives appeared to be implemented at a slow pace in the U.S. The recent proposals in the U.S serve as indication, not only of the willingness to adopt Basel rules, but also reveal the extra steps being taken to ensure that financial stability is fostered and more rigid and stringent measures to avert another global scale crisis.

Arguments favoring 2013 Basel Committee updates over those 2013 proposals introduced in the US, are partly based on the following:

1) The fact that revisions and proposals undertaken in the U.S are premised on Tier 1 capital, instead of higherquality Core Tier 1.

2) Recent Basel Guidelines (June 2013) are more extensive in scope as opposed to the denominator of the U.S. leverage ratios which are based on original 2010 Basel Leverage ratios.

3) The cumbersome nature of the supplementary leverage ratio - which in the opinion of many commentators, will be more burdensome for subsidiaries of BHCs to comply with than the generally applicable leverage ratio for U.S. banks. It is calculated using a ,tighter definition of Tier 1 capital in the numerator and the denominator includes off-balance sheet exposures such as the grossing-up of derivatives to include collateral and cash“ (which is why many banks are likely to want to evade as much inclusion of such derivatives in the denominator

${ }^{41}$ Ibid at page 24 
- given the value/magnitude of derivatives). The $6 \%$ standard is considered by many to be onerous for bank subsidiaries covered by the proposal and may encourage banking groups to conduct certain activities, such as derivatives based activities, away from their subsidiaries.

Furthermore, an introduction of the supplementary leverage ratio, it is most likely envisaged, will result in lower dividends being distributed by the BHCs.

4) The focus accorded to disclosures of the numerator and denominator components of the Basel Leverage Ratios in the Basel June 2013 Guidelines.

According to paragraph 43 of the Consultative Document on the Revised Basel III Leverage Ratio framework and Disclosure Requirements: ${ }^{42}$

- Public disclosure by banks of their Basel III leverage ratios commences on 1st January 2015

- To enable market participants reconcile leverage ratio disclosures with banks' published financial statements from period to period, and to compare the capital adequacy of banks across jurisdictions with varying accounting frameworks, it is important that banks adopt a consistent and common disclosure of the main components of the leverage ratios while reconciling to their published financial statements.

Paragraphs 44 as well as $45^{43}$ underline the Committee's commitments to, as well as its realization of the need for focus on measures and initiatives aimed at facilitating the harmonization and consistency of disclosure requirements across various jurisdictional frameworks which would also result in the facilitation of the realization of the Basel Committee's objectives and aims.

\section{Enhanced Supplementary Leverage Ratios (ESLR) - 2014 U.S Revisions}

In April 2014, the Federal Deposit Insurance Corporation (FDIC), the Board of Governors of the Federal Reserve System (the FRB) and the Office of the Comptroller of the Currency (the OCC) took two important steps: ${ }^{44}$

${ }^{42}$ June 2013, Bank for International Settlements Publications, page 11

${ }^{43}$ Which states that ,to facilitate consistency and ease of use of disclosures relating to the composition of the leverage ratio, and to mitigate the risk of inconsistent formats undermining the objective of enhanced disclosure, the Basel Committee has agreed that internationally active banks across Basel member jurisdictions, will be required to publish their leverage ratio according to a common template."

${ }^{44}$ See Sullivan \& Cromwell LLP, „Bank Capital: Supplementary Leverage Ratio, Federal Banking Agencies Propose Revisions to the Supplementary Leverage Ratio's Exposure Measure and Approve Final Rules Implementing an Enhanced Supplementray Levrage Ratio for the Largest U.S Baking Organizations“ April 162014

In April 2014, the Federal Reserve Board, the Federal Deposit Insurance Corporation (FDIC), and the Office of the Comptroller of the Currency (OCC) "adopted a final rule to strengthen the leverage ratio standards for the largest, most interconnected U.S. banking organizations. The final rule applies to U.S. top-tier bank holding companies with more than $\$ 700$ billion in consolidated total assets or more than $\$ 10$ trillion in assets under custody (covered BHCs) and their insured depository institution (IDI) subsidiaries." See Agencies Adopt Enhanced Supplementary Leverage Ratio Final Rule and Issue Supplementary Leverage Ratio Notice of Proposed Rulemaking http://www.federalreserve.gov/newsevents/press/bcreg/20140408a.htm 
1) The Agencies approved a notice of proposed rulemaking (the "NPR", and the rules stipulated therein, the "Proposed Rules") which would revise the definition and scope of the "total leverage exposure", which is the denominator of the SLR (hence, also the denominator of the enhanced SLR).

2) The Agencies approved final rules (the "Final Rules") that would effectively result in a rise from the SLR's usual 3\% minimum SLR standard to 5\% for bank holding companies with total consolidated assets of more than $\$ 70$ billion or assets under custody of more than $\$ 10$ trillion and $6 \%$ for their insured depository institution subsidiaries.

Following the issue of the January 2014 revised Basel leverage ratios, Pricewaterhouse were of the opinion that U.S regulators would not only have to decide whether an alteration of the exposure calculations of the supplementary leverage ratio (SLR) would be necessary (as a means of further harmonizing with the January 2014 revised Basel leverage ratios), but also decide if they would, more importantly, adjust the Enhanced Supplementary Leverage Ratios. ${ }^{45}$ It is Pricewaterhouse' view that U.S regulators are unlikely to lower the ESLR's $2 \%$ buffer - primarily attributable to the fact that U.S regulators are considered to view the ESLR as a "needed complement to risk-based capital standards (as opposed to a "back-stop"). ${ }^{46}$

The need for consistency in the implementation of Basel requirements and regulations is all the more vital and necessary if practices relating to regulatory capital arbitrage are to be minimized and controlled. Differences in the implementation of Basel requirements and rules across various jurisdictions are evident from the very stringent application of rules in certain jurisdictions - as is recently evidenced by the U.S initiatives aimed at increasing Basel III Leverage ratios (above global standards) to those jurisdictions where more lax approaches have been adopted.

Evidence which highlights the fact that different countries could be inconsistently implementing parts of the Basel rules and regulations - either by consolidating or weakening the original requirements, is illustrated through the following: ${ }^{47}$

- In the EU, in relation to the Capital Requirements Directive/Regulation IV (CRD/RIV) - where based on evidence from latest proposals and negotiations, EU member states will assume greater independence in their ability to increase capital requirements.

- In China, where the implementation framework for Basel III is considered to be more stringent than the international standard (with a requirement of a higher core tier 1 capital adequacy ratio - 5\% as opposed to $4.5 \%$, as well as a higher leverage ratio requirement of $4 \%$ as opposed to $3 \%$ ).

\footnotetext{
${ }^{45}$ PricewaterhouseCoopers, "Regulatory Brief : Basel Leverage Ratios: No Cover For US Banks" January 2014 http://www.pwc.com/en_US/us/financial-services/regulatory-services/publications/assets/fs-reg-brief-dodd-frank-basel-leve rage-ratio.pdf

${ }^{46}$ Ibid. This view being shared by PwC even though "the impact of the ESLR's $2 \%$ buffer is further accentuated by the competitive advantage which the now more aligned revised January 2014 leverage ratio provides non-US banks."

${ }^{47}$ See JP Morgan, 'Basel III Implementation: Is the Industry Running Out of Time?' http://www.jpmorgan.com/tss/General/Basel_III_implementation_Is_the_industry_running_out_of_time_/13205045120 62
} 
- In the U.S, as discussed throughout this paper, through recent proposals relating to standard and supplementary leverage ratios.

Having highlighted the above, it is also worth mentioning that "over compliance" with rules (and particularly where it appears that such rules or ratios appear to be insufficient) - as indicated by the supplementary ratios in the U.S, is certainly much better than under compliance. What may be regarded as over compliance for a particular jurisdiction may not necessarily be the case for another. Conversely what may be required for minimal compliance purposes in certain jurisdictions may prove inadequate for certain major economies. Hence it may be necessary to invent additional rules or supplement existing legislation and rules as a means of achieving longer term efficiency in terms of overall costs and benefits to be generated from implementing new innovative - as well as complementary measures.

\section{E. Credit Risk Measurements, Internal Models and Sound Bank Stress Testing Techniques As Complementary Measures}

Sound stress testing practices, as identified by the Basel Committee, should embrace the provision of forwardlooking assessments of risk, complement information from models and historical data, - as well as constitute an integral part of capital and liquidity planning. Even though the Basel capital accords have evolved, recurring lessons related to failures of mechanical approaches such as those of bank stress testing techniques, provide reflections of the fact that internal ratings based models should not always be expected to provide credible results where standardization, particularly, is unduly resorted to.

The need for better risk sensitive based measurements evolved with the introduction of Basel II. The original Basel Capital Accord had been criticized for its crude measurements, application to wide risk categories and broad application - which not only resulted in practices related to regulatory capital arbitrage but also the need to focus on other classes of risks - as opposed to its primary focus, namely, credit risk.

Basel II therefore signaled the era of the introduction of internal based modeling approaches which were designed to address the broad approach to risk measurements, reduce the tendencies for regulatory arbitrage practices and embrace wider classes of risks, namely, operational and market risk - in line with the evolution of risks within the financial environment. According to the 1999 BCBS Working Paper, Capital Requirements and Bank Behavior "the original Basel Accord, with its very broad risk categories, was found to give scope for banks to arbitrage between their economic assessment of risk and capital requirements - this factor being critical in allowing greater alignment of internal risk measures and regulatory capital under Basel II." Basel II also acknowledged the fact that the standardized approach to measuring credit and market risk could not sufficiently account for the accurate measurement of risks which were prevalent within the financial environment. "Banks must calculate capital requirements for credit, market and operational risk using either a prescribed standardised approach or, with supervisory approval, an internal model-based method." 
Standardization is certainly required for the basis of comparability - however, a healthy balance needs to be struck between the extent of standardization and the need to obtain credible, reliable and accurate results. Hence we observe a move from the "one size fits all" approach adopted under the original 1988 Basel Capital Accord to a more risk sensitive Basel II. However, such risk sensitivity came with a price. Whilst criticisms were raised in relation to the 1988 Capital Accord's tendencies to encourage capital arbitrage practices, Basel II's internal models were criticized as being unduly sensitive and encouraging pro cyclical effects (that is, the amplification of business cycle fluctuations - resulting in contracted lending during recessive periods), in its measurements.

The Basel III Leverage ratio has also been criticized for not being risk sensitive enough - and that instead of facilitating its intended goal of comparability, it has rather, resulted in the different application of jurisdictional accounting standards and treatments in a bid to ensure that prevailing jurisdictional principles and standards which underpin several key financial activities, are not over-ridden.

As is the case with the Basel Leverage Ratio, bank stress techniques should not be used in isolation. In effectively performing their roles as monitoring, predictive devices and risk management tools, they will greatly assist Basel Leverage ratios, as well as the risk based capital adequacy framework, in achieving their intended aims and objectives. According to the Basel Committee, ${ }^{48}$ the financial crisis not only revealed weaknesses in organizational aspects of stress testing programmes in the sense that prior to the crisis, stress testing at some banks was carried out on an isolated basis ( by the risk function with little interaction with business areas), but also the fact that test analyses were not credible.

Furthermore, the mechanical approaches adopted by certain organizations resulted in inaccurate and unreliable results being generated. As rightly observed, by the Committee, „mechanical approaches can either fully take account of changing business conditions nor incorporate qualitative judgments from across the different areas of a bank."

\section{Sound Stress Testing Practices and Historical Relationships: The Need For Forward-looking Assessments of Risk}

It has been identified by the Committee that most risk management models, including stress tests, use historical statistical relationships to assess risk - under the assumption that risk is driven by a known and constant statistical process, that historical relationships constitute a good basis for forecasting the development of future risks. The Financial Crisis, according to them, has revealed serious flaws with relying solely on such an approach.

\footnotetext{
48 See Basel Committee on Banking Supervision, Principles for Sound Stress Testing Practices and Supervision May 2009 at pages $8-12 \mathrm{http}: / / w w w . b i s . o r g / p u b l / b c b s 155 . h t m$
} 
Other identified weaknesses of stress testing programmes, as identified by the Committee include: ${ }^{49}$

- Stress testing frameworks were usually not flexible enough to respond quickly as the crisis evolved (for example, inability to aggregate exposures quickly, apply new scenarios or modify models).

- Weaknesses in infrastructure limited the ability of banks to identify and aggregate exposures across the bank. This weakness limits the effectiveness of risk management tools - including stress testing.

- An appropriately conducted firm-wide stress test would have beneficially drawn together experts from across the organization. For example, the expertise of retail lenders, who in some cases were reducing exposure to US subprime mortgages, should have counteracted the overly optimistic outlook of traders in securities backed by the same subprime loans.

- That particular risks that were not covered in sufficient detail in most stress tests include: the behavior of complex structured products under stressed liquidity conditions; basis risk in relation to hedging strategies; pipeline or securitization risk; contingent risks; and funding liquidity risk.

- That, had stress tests adequately captured contractual and reputational risk associated with off-balance sheet exposures, concentrations in such exposures may have been avoided.

The above flaws not only highlight the difficulties associated with the accurate prediction and measurement of risks, but also why objectives of the Basel III ratio - as well as subsequent revisions thereto since its introduction in December 2010, have placed considerable focus on adequately accounting for risk exposures and comprehensive risk coverage, as well as the degree of flexibility permitted with the netting of certain transactions - as evidenced by the January 2014 revisions. From the above, the ever present and important area of liquidity risks and the need to address such risks is also highlighted. The recent Financial Crisis certain brought to light many weaknesses - which the Basel III Leverage ratio is intended to remedy: namely, constraining the build-up of leverage in the financial sector as a means of averting de-stabilising deleveraging occurrences which can pose threats to the financial system - an occurrence from which certain institutions, which had been operating well within the stipulated capital adequacy ratios during the Financial Crisis, were not exempt.

\section{F. Conclusion}

The effects and consequences of the cumbersome nature of the supplementary leverage ratio, it is envisaged, will induce some banking groups to conduct certain activities, such as derivatives based ventures, away from their subsidiaries. Other consequences of recently introduced proposals in the U.S (on Basel III), include a reference by Myles to a separate Federal Reserve proposal - which from December 2012, ,requires certain foreign banks to establish a U.S intermediate holding company to house their operations."In Myles opinion, if these holding companies' asset value is significantly high, they would have to comply with the higher leverage ratios.

${ }^{49}$ see ibid

${ }^{50}$ Myles also adds that this is exacerbated by the fact that foreign banks are the biggest dealers in US treasuries - ,which are penalized by un-weighted measures such as leverage ratios" and that further, it is also possible that branches might have to comply with U.S leverage ratios - based on how the Fed Reserve construed its comparability test." See D Myles, 'How U.S 5\% Leverage Ratio Could Catch Foreign Banks' <http://www.iflr.com/Article/3234308/Banking/How-US-5-leverageratio-could-catch-foreign-banks.html 
As already re-iterated in the paper, the impact of the ESLR's $2 \%$ buffer is further accentuated by the "competitive advantage" which the now more aligned revised January 2014 leverage ratio provides non-US banks. From the perspective of other off-balance sheet exposures, the reduced exposure of OBS commitments via the January 2014 Basel revisions is considered to result in a treatment which is more beneficial to foreign banks than the Supplementary Leverage Ratio's treatment. ${ }^{51}$ This being the case since comparatively higher capital costs for US banks (in providing credit commitments to retail and corporate borrowers) are considered ${ }^{52}$ to result from the disparity in CCFs for commitments.

U.S banks however benefit from the perspective of Securities Financing Transactions - since as rightly argued, ${ }^{53}$ even though the January 2014 Basel revisions "closes the gap in ability to net on- balance sheet SFT exposures" - with respect to the Supplementary Leverage Ratio, U.S banks still benefit from the continued exclusion of Off Balance Sheet SFTs from leverage exposure.

Despite the merits of improved consistency and harmonization in the implementation of Basel rules and regulations - such merits including enhanced facilitation of disclosure and transparency, a balance also needs to be struck between the need to avoid a ,one size fits all "situation whereby the needs of respective jurisdictions are not met.

The need to achieve more relevant and accurate results is evidenced by the evolution of the Basel capital accords from the rather „crude“ original 1988 Capital Accord (which even though risk based, focused exclusively on credit risk and did not apply risk weights in a specific and tailor made manner to asset classes) to the adoption of more tailor made and specific internal ratings models.

Whilst comparability and consistency, which is sometimes attributed to simpler and cruder models, may be desired, it is also vital that results derived from such models reflect the reality and accuracy of prevailing conditions - hence the need to provide for models which provide and generate credible results.

As identified by the Basel Committee on Banking Supervision in its discussion paper „The Regulatory Framework: Balancing Risk Sensitivity, Simplicity and Comparability, ${ }^{654}$ the disadvantages attributed to undue complexity and reduced comparability in the capital framework, potentially“ include:

- Increased difficulties for bank management in understanding the regulatory regime;

- The challenges arising in capital planning;

- Less accurate risk assessments;

- The creation of regulatory gaps and opportunities for arbitrage;

- An undermining of the ability of supervisors to effectively assess the capital adequacy of banks

- Impediments presented to the effective review of the capital management process by supervisors.

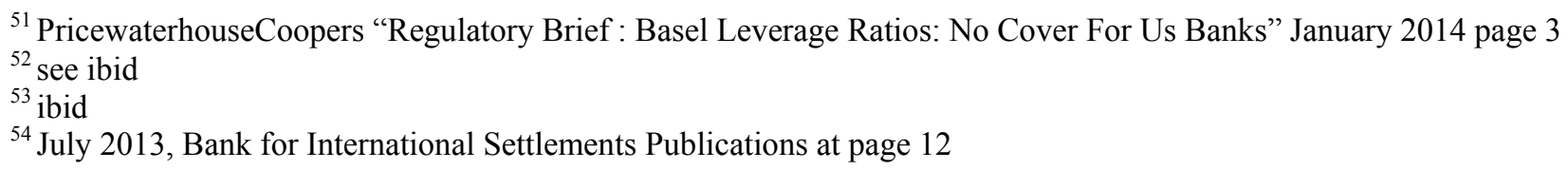


Achieving an appropriate balance between consistency, comparability, standardization and the need for accurate results is demonstrated by the Federal Reserve's flexible approach in applying bank stress testing techniques. As reported, ${ }^{55}$ through the provision of a common set of scenarios to all firms, the results of company-run and supervisory stress tests for bank holding companies are intended to be based on comparable underlying assumptions. To further enhance comparability, the supervisory stress tests and company-run stress tests conducted under the Dodd Frank stress test rules use the same set of capital action assumptions. ${ }^{56}$

The importance of adequately addressing liquidity risks cannot be over-emphasized. Data generated from family firms as well as other firms whose systems and structures are regarded as synonymous to those of concentrated ownership, are also therefore of vital importance and do indeed provide fertile ground for future research. It will also be vital for such concentrated ownership structures to review and upgrade the status accorded to audits and audit committees if they are to effectively and maximally achieve goals and objectives of the Base 1 Committee's risk based adequacy framework, leverage ratios - as well as improve on attributes of good corporate governance practices - namely accountability, adequate supervision, monitoring, transparency and disclosure.

The recently introduced Supplementary and Enhanced Supplementary Ratios in the U.S and other jurisdictions, has also highlighted the fact that a "one size fits all" standard cannot always apply if certain regulatory - as well as jurisdictional goals are to be achieved. If harmonization is to be achieved, particularly with major players and economies, then standards and regulations will have to accommodate such major economies" prevailing regulatory framework. The GAAP, which influences a lot of repo activities in the United States, for example, for this reasons cannot be disregarded.

${ }^{55}$ See Dodd-Frank Act Stress Test 2013: Supervisory Stress Test Methodology and Results March 2013 at pages 5 and 6 B O A R D OF G O VER N OR S OF T HEFE DER A L R ES ER VES Y S T E M http://www.federalreserve.gov/newsevents/press/bcreg/dfast_2013_results_20130314.pdf

${ }^{56}$ ibid 


\section{G. References}

Basel Committee on Banking Supervision, 'Capital Requirements and Bank Behavior: The Impact of the Basel Accord' Basel Committee on Banking Supervision Working Papers April 1999

Basel Committee on Banking Supervision, 'Consultative Paper on a New Capital Adequacy Framework' $3^{\text {rd } J u n e ~} 1999$ http://www.bis.org/press/p990603.htm

Basel Committee on Banking Supervision, Capital Requirements and Bank Behavior: The Impact of the Basel Accord, BCBS Working Paper No. 1,1999

Basel Committee on Banking Supervision, Capital Requirements and Bank Behaviour: The Impact of the Basel Accord Basel Committee on Banking Supervision Working Papers No 1 April 1999

Basel Committee on Banking Supervision, 'The Internal Ratings Based Approach' Supporting Document to the New Basel Capital Accord 2001 http://www.bis.org/publ/bcbsca05.pdf

Basel Committee on Banking Supervision, Consultative Document, Standard Approach to Credit Risk, Supporting Document to the New Basel Accord January 2001 http;//

www.bis.org/publ/bcbsca04.pdf

Basel Committee on Banking Supervision, Principles for Sound Liquidity Risk Management and Supervision Sept 2008 at page 1

$<$ http://www.bis.org/publ/bcbs144.htm>

Basel Committee on Banking Supervision, Principles for Sound Stress Testing Practices and Supervision May 2009 at pages 8-12 http://www.bis.org/publ/bcbs155.htm

Basel Committee on Banking Supervision, Consultative Document: The Non Internal Model Method for Capitalizing Counterparty Credit Risk Exposures (June 2013) http://www.bis.org/publ/bcbs254.htm

Basel Committee on Banking Supervision, Consultative Document Revised Basel III Leverage

Ratio Framework and Disclosure Requirements June 2013 http://www.bis.org/publ/bcbs251.pdf

Basel Committee on Banking Supervision, Discussion Paper 'The Regulatory Framework: Balancing Risk Sensitivity, Simplicity and Comparability“ July 2013 Bank for International Settlements Publications

Basel Committee for Banking Supervision, 'Global Systemically Important Banks: Assessment Methodology and the Additional Loss Absorbency Requirement' July 2013

http://www.bis.org/publ/bcbs207.pdf 
Basel Committee on Banking Supervision, "Basel III Leverage Ratio Framework and Disclosure Requirements" January 2014

http://www.bis.org/publ/bcbs270.htm

Basel Committee on Banking Supervision, "The Standardized Approach for Measuring Counterparty Credit Risk Exposures (March 2014) Available at http://www.bis.org/publ/bcbs279.htm

Basel Committee on Banking Supervision, "Supervisory Framework for Measuring and Controlling Large Exposures - Final Standard" April 2014

http://www.bis.org/publ/bcbs283.htm

Bennedsen M, Perez-Gonzalez F and Wolfenzon D, "The Governance of Family Firms”

http://web.stanford.edu/ fperezg/familyfirmresearch.pdf

DB Research, 'Leverage Ratio: Pressure on Europe is Rising'

http://www.dbresearch.de/servlet/reweb2.ReWEB?addmenu=false\&document=PROD0000000000317297

\&rdShowArchivedDocus $=$ true\&rwnode=DBR_INTERNET_DEPROD $\$$

NAVIGATION\&rwobj=ReDisplay.Start.class\&rwsite=DBR_INTERNET_DE-PROD

Federal Reserve, 'Regulatory Capital Rules: Regulatory Capital, Enhanced Supplementary Leverage

Ratio Standards for Certain Bank Holding Companies and their Subsidiary Insured Depository

Institutions' http://www.federalreserve.gov/newsevents/press/bcreg/bcreg20130709a1.pdf.

Federal Reserve, Regulatory Capital Rules: Regulatory Capital, Implementation of Basel III, Capital Adequacy, Transition Provisions, Prompt Corrective Action, Standardized Approach for Risk-weighted Assets, Market Discipline and Disclosure Requirements, Advanced Approaches Risk-Based Capital Rule, and Market Risk Capital Rule

http://www.federalreserve.gov/bcreg20130702a.pdf

Federal Reserve, 'Dodd-Frank Act Stress Test 2013: Supervisory Stress Test Methodology and Results' March 2013

B O A R D O F G O VER N OR S OF T H E F E D R A L R E S E R V E S Y S T E M _ http://www.federalreserve.gov/newsevents/press/bcreg/dfast 2013 results 20130314.pdf

Federal Reserve, Agencies Adopt Enhanced Supplementary Leverage Ratio Final Rule and Issue Supplementary Leverage Ratio Notice of Proposed Rulemaking http://www.federalreserve.gov/newsevents/press/bcreg/20140408a.htm

Financial Stability Board, Update of Group of Global Systemically Important Banks (G-SIBs) (Nov. 1, 2012) http://www.financialstabilityboard.org/publications/r_121031ac.pdf 
Fu L, Lu-Andrews R and Y-Thompson Y "Liquidity and Corporate Governance:Evidence From Family Firms" http://papers.ssrn.com/sol3/papers.cfm?abstract id=2433764

IIF, ISDA, BCBS Discussion Paper - The Regulatory Framework: Balancing Risk Sensitivity, Simplicity and Comparability October 2013

Jones D, Emerging problems with the Basel Capital Accord: Regulatory Capital Arbitrage and Related Issues Journal of Banking \& Finance 24 (2000) 35 58 Elsevier Publications

Lastra RM and Wood G, „The Crisis of 2007 - 09: Nature, Causes and Reactions“ Journal of International Economic Law 13(3) at pages 531 and 532

Morgan JP, 'Basel III Implementation: Is the Industry Running Out of Time?' -

http://www.jpmorgan.com/tss/General/Basel_III_implementation_Is the industry running out of time /1320 $\underline{504512062}$

Myles D, 'How U.S 5\% Leverage Ratio Could Catch Foreign Banks'

$<$ http://www.iflr.com/Article/3234308/Banking/How-US-5-leverage-ratio-could-catch foreignbanks.html

Ojo M, "Why the Traditional Principal Agent Theory May No Longer Apply to Concentrated Ownership Systems and Structures" http://mpra.ub.uni-muenchen.de/50832/1/MPRA paper 50832.pdf

Ojo M, Fair Value Accounting and Procyclicality: Mitigating Regulatory and Accounting Policy Differences Through Regulatory Structure Reforms and Enforced Self Regulation March 2011 http://mpra.ub.unimuenchen.de/29314/

Polk D, 'Basel III Leverage Ratio: US Proposes American Add-On, Basel Committee Proposes Important Denominator Changes“ July 192013

Polk, D Visual Comparison Chart : US Supplementary Leverage Ratio (SLR) vs Basel III Leverage Ratio http://blog.usbasel3.com/category/leverage-ratios/

PricewaterhouseCoopers, "Regulatory Brief: Basel Leverage Ratios:No Cover For US Banks"January2014 http://www.pwc.com/en_US/us/financial-services/regulatory-services/publications/assets/fs-reg-brief-dodd-fra nk-basel-leverage-ratio.pdf

Rodriguez Valladares M, 'Why Basel' Latest Leverage Ratio is Better' _ http://www.americanbanker.com/bankthink/why-basels-latest-leverage-ratio-is-better-1060635-1.html

Saidenberg M and Schuermann T, 'The New Basel Capital Accord and Questions for Research' (2003) Wharton Financial Institutions Center Working Paper 2003 